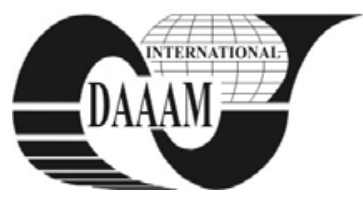

Annals of DAAAM for 2011 \& Proceedings of the 22nd International DAAAM Symposium, Volume 22, No. 1, ISSN 1726-9679 ISBN 978-3-901509-83-4, Editor B. Katalinic, Published by DAAAM International, Vienna, Austria, EU, 2011 Make Harmony between Technology and Nature, and Your Mind will Fly Free as a Bird Annals \& Proceedings of DAAAM International 2011

\title{
FEM ANALYSES OF THE RADIATION IN HEATING FORGING FURNACE
}

\author{
TIKAL, F[ilip] \& DUCHEK, M[ichal]
}

\begin{abstract}
The purpose of this study was to identify possible causes of longitudinal surface cracks found during early stages of ingot breakdown. However, these cracks need not necessarily form during forging or as a result of poor quality of the surface in metallurgical terms. Under certain conditions, they may occur even as the ingot is being heated in the furnace to the forging temperature. The cracks probably form within a few minutes after placing the ingot in the furnace as a result of the temperature gradient, which is most severe on the ingot surface. A numerical model was created to represent the case of two ingots in a furnace. Upon casting, the ingots are cooled down to no more than $600^{\circ} \mathrm{C}$ and then placed in a furnace at $1,100-1,200^{\circ} \mathrm{C}$. Numerical simulations were used to analyse their internal stresses and temperatures.

Key words: ingot cracks, furnace, radiation, FEM model
\end{abstract}

\section{INTRODUCTION}

Ingots from 34CrNiMo6 material sometimes develop cracks, which are often detected during forging. First steps to a remedy to this problem led to modifying the forging process. This, however, did not bring the desired results. Consequently, a theory was formed that these cracks do not occur during forging but occur earlier: during soaking. Inspection showed that these cracks always form in certain locations on the ingot side, which faced the furnace lining (Jandoš, 2009).

This fact led to a closer look at the manufacturing process. In production, cast ingots cool down to about $600^{\circ} \mathrm{C}$ but no less than $500^{\circ} \mathrm{C}$. They are then placed in a furnace at a temperature of $1,100-1,200^{\circ} \mathrm{C}$. This leads to a question whether it might be this thermal shock, which initiates the cracks that propagate during forging. For testing such a hypothesis, plant experiments with expensive ingots are impractical. This is why numerical simulation was chosen for testing these assumptions.

\section{NUMERICAL SIMULATION}

The exact conditions for numerical simulation were the first item to be specified. Upon consulting the manufacturer, the process boundary conditions for calculation were defined, as shown in Fig. 1. The calculations describe a time period of up to 5 minutes after placing the ingot in the furnace.

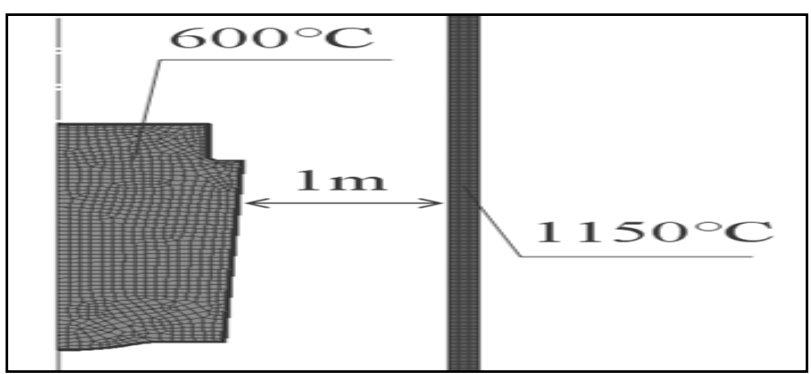

Fig. 1. Schematic representation of the ingot and the furnace wall
The pilot simulation of this complex situation was conducted as 2D analysis, using the simulation tools DEFORM and MSC.Marc/Mentat. Both programs are based on finite element method. In order to improve the accuracy of results, an additional 3D simulation was carried out using MSC.Marc/Mentat.

\subsection{D Numerical Simulation in DEFORM}

The input parameters for 2D simulations were set as follows: ingot temperature: $600^{\circ} \mathrm{C}$, furnace lining temperature: $1,150^{\circ} \mathrm{C}$, the distance between the ingot and the furnace wall: $1 \mathrm{~m}$, as in Fig 1. For better precision of the calculation, furnace parameters, such as materials properties of individual walls, burner locations and other factors were taken into account. An axially-symmetric model was used for faster computation.

After the ingot is placed in the furnace, the thermal shock takes effect; typically for several minutes.

Once the numerical model was refined, the input conditions were adjusted. In alternative calculations, the initial temperature of the ingot in the furnace was changed to $500^{\circ} \mathrm{C}$ and the distance from the furnace was set at $1.5 \mathrm{~m}$. A total of four numerical analyses were conducted using the axially symmetric model, combining various temperatures and distances, as in Tab. 1. The temperature and stress on the ingot surface upon 5 minutes in the furnace are shown in Tab. 1. They suggest that increasing the distance from the furnace wall to $1.5 \mathrm{~m}$ does not significantly affect the stress magnitude. A greater difference was found after reducing the initial ingot temperature to $500^{\circ} \mathrm{C}$. In such case, the stress increases by about $50 \mathrm{MPa}$ and the temperature declines by about $80^{\circ} \mathrm{C}$ (Duchek et al., 2010).

\subsection{D Numerical Simulation in MSC.Marc/Mentat}

Results of 2D simulations in DEFORM were verified through another 2D analysis in MSC.Marc/Mentat. It involved an ingot with the temperature of $600^{\circ} \mathrm{C}$ placed in a furnace at $1,150^{\circ} \mathrm{C}$ in a $1 \mathrm{~m}$ distance from the furnace lining (Tikal \& Urbánek, 2010).

Results of MSC.Marc/Mentat 2D simulation were virtually identical to those of DEFORM 2D simulation.

\subsection{D Numerical Simulation in MSC.Marc/Mentat}

After the results of 2D simulations performed in the two simulation systems were found to match, 3D simulation was only run using MSC.Marc/Mentat.

The comparative calculation in DEFORM 3D was not carried, as the $3 \mathrm{D}$ simulation is generally time consuming and costly.

\begin{tabular}{|c|c|c|c|c|}
\hline \multirow{3}{*}{$\begin{array}{l}\text { Initial ingot } \\
\text { temperature } \\
{\left[{ }^{\circ} \mathrm{C}\right]}\end{array}$} & \multicolumn{4}{|c|}{ Ingot - furnace wall distance [mm] } \\
\hline & \multicolumn{2}{|c|}{1000} & \multicolumn{2}{|c|}{1500} \\
\hline & $\begin{array}{l}\text { Temp. } \\
{\left[{ }^{\circ} \mathrm{C}\right]}\end{array}$ & $\begin{array}{l}\text { Stress } \\
{[\mathrm{MPa}]}\end{array}$ & $\begin{array}{l}\text { Temp. } \\
{\left[{ }^{\circ} \mathrm{C}\right]}\end{array}$ & $\begin{array}{l}\text { Stress } \\
\text { [MPa] }\end{array}$ \\
\hline 600 & 749 & 473 & 745 & 461 \\
\hline 500 & 667 & 528 & 663 & 512 \\
\hline
\end{tabular}

Tab. 1. Summary of results of 2D simulations in DEFORM 


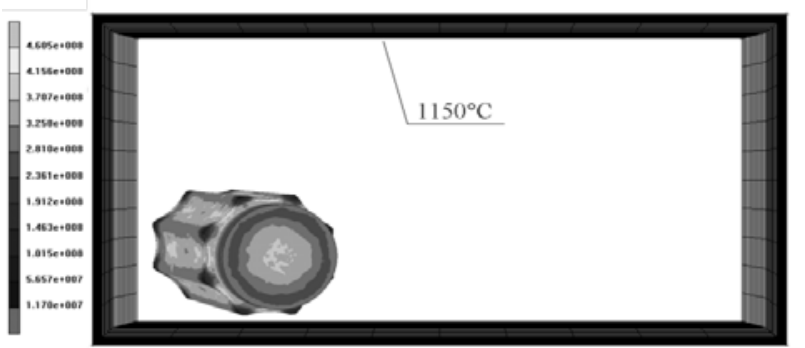

Fig. 2. Stress distribution in the ingot after 5 minutes

Once the 3D temperature analysis was refined, the stress calculations were performed. The results of the last stage of temperature calculation for the time instant of 5 minutes after placement in the furnace were uploaded to explore the stress state of the ingot. Eventually, the task was converted to a loadcase coupled problem which allows both temperature and stress to be monitored at every time step of the analysis.

Radiation was calculated with the aid of view factor Monte Carlo method, in which areas of all finite elements within interior walls of the furnace and the ingot surface are calculated. The mutual visibility of objects based on this description is used for emitting a specified number of rays to represent the radiation. Once the radiation data is complete, it is possible to compute the temperature and stress fields in the ingot for any particular instant up to the end of the required 5 minute period.

First, 3D simulation only involved one ingot in the furnace. This was compared with results of $2 \mathrm{D}$ simulation where an ingot with the initial temperature of $600^{\circ} \mathrm{C}$ was placed in a furnace at $1,150^{\circ} \mathrm{C}$ in a $1 \mathrm{~m}$ distance from the wall, see Fig. 2 .

The other variant involved two ingots parallel to each other and $1 \mathrm{~m}$ apart, see Fig. 3. The input parameters were identical to those of the single ingot simulation. The impact of shading between ingots was explored. The middle ingot was expected to show different temperatures, and thus different stress state. This simulation model proved the inconsiderable impact of shading. The difference between this variant and a single ingot in the furnace is most obvious in the shaded ingot, on the plane facing the furnace wall. The difference between stresses in ingots on this plane is to $20 \%$ at the time of strongest shading effect.

\section{CONCLUSION}

Numerical modelling was carried out to explore the impact of several factors on cracks forming during soaking of ingots. Two simulation tools were used: DEFORM 2D and MSC.Marc/Mentat. The input parameters for 2D simulation included ingot temperatures of 600 and $500^{\circ} \mathrm{C}$ and distances between the ingot and furnace wall of 1 and $1.5 \mathrm{~m}$. These distances were not found to have any substantial impact on stress levels in the ingot surface.

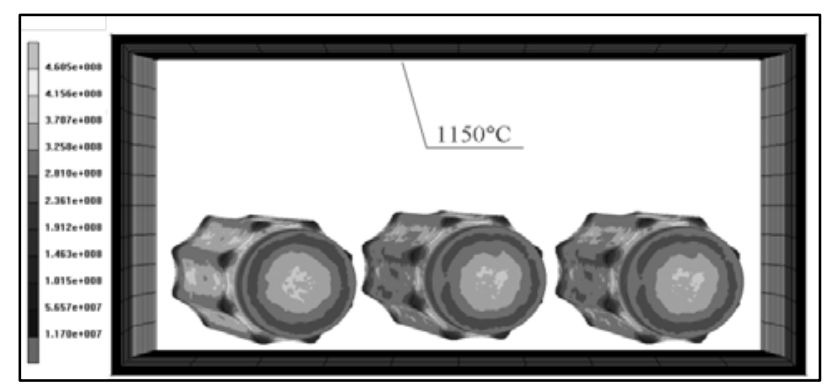

Fig. 3. Stress distribution in ingots shaded from radiation

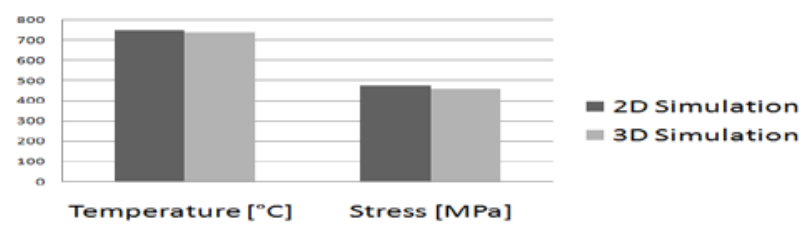

Fig. 4. Differences between results of 2D and 3D simulations

2D numerical simulations have shown that ingots may develop large stresses due to thermal shock. In an ingot at $500^{\circ} \mathrm{C}$, which is placed in a furnace at $1,150^{\circ} \mathrm{C}$ and in the distance of about 1 metre from the furnace wall, surface stresses after 5 minutes may reach $528 \mathrm{MPa}$.

The differences between stress values in a single ingot in a furnace calculated by 2D and 3D simulations are negligible. As Fig. 4 shows, after 5 minutes the stress difference was minimal, reaching $12 \mathrm{MPa}$.

When multiple ingots were placed in the furnace, the shading from radiation took effect. The stress in the surface of the shaded ingot on the side facing the furnace wall is $20 \%$ lower than that in the non-shaded ingot. The expected stress level thus declines to about $400 \mathrm{MPa}$. Experience suggests that this stress level is not critical to cracking. For accurate mapping of stress distribution in the material, one needs to consider the arrangement of ingots in the furnace.

Numerical simulations provided a good description of the behaviour of a single and multiple ingots placed in a forge furnace for heating to the forging temperature. Therefore, the radiation heat transfer must not be neglected in similar calculations.

The calculated stress magnitudes can be used for predicting ingot cracking. Results of the analysis were used by the company PILSEN STEEL for altering the soaking procedure in order to minimize the risk of cracking caused by the thermal shock.

Follow-up research in this field should focus on optimizing various alternatives of placing various ingots in a furnace. It would be useful to be able to identify any breach of job card instruction during heating, to prepare relevant documentation and include this type of data in the numerical model.

\section{ACKNOWLEDGEMENTS}

This paper includes results achieved within the project FTTI1/490 - Zvýšení konkurenceschopnosti hutních válců (Improving the Competitiveness of Metallurgical Rolls).

\section{REFERENCES}

Jandoš, F. et al. (2009). Výzkum příčin výrobních vad hmotných výkovků pro lodní a energetický průmysl, Project final report: MPO TANDEM FT - TA3/083, PILSEN STEEL s.r.o., unpublished

Duchek, M., Jandoš, F. \& Tikal, F. (2011). Numerické simulace vlivu sálání pecní vyzdívky na ingoty z materiálu 34cRNiMo6, Proceedings of METAL 2011, Brno, Czech Republic, ISBN 978-80-87294-22-2, pp. 48 - 49

Tikal, F.; Urbánek, M. (2010). Simulace sálání v peci v programu MSC.Marc/Mentat, Proceedings of 2010 User Meeting MSC.Software s.r.o., CD-ROM, Brno: MSC

Lu Q., Bai C., Rong Y.-K. (2000). Loaded Furnace Temperature Modeling and Analysis, Proceedings of $20^{\text {th }}$ ASM Heat Treating Conference, October 9-12, St. Louis, MO, USA, K. Funatani, G. E. Totten (Ed.), pp. 635 - 640

Qi H., Ruan L. \& Tan J. (2005), Development of a finite element radiation model applied to two-diemnsional participating media. Heat Transfer - Asian Research, Vol. 34, Issue 6, pp. 386 - 395 